\title{
Pengembangan Modul Pembelajaran Fisika Berbasis Guided Inquiry pada Materi Alat-Alat Optik Kelas XI MA/SMA
}

\author{
L. M. Azizah*, J. B. Poernomo, dan M. I. Faqih \\ Program Studi Pendidikan Fisika Universitas Islam Negeri Walisongo Semarang \\ *email:lutfita97azizah@gmail.com
}

Received: August 05th 2019. Accepted: August 28th 2019. Published: August 29th 2019

\begin{abstract}
Abstrak
Penelitian ini bertujuan untuk menghasilkan modul pembelajaran berbasis guided inquiry pada materi alat-alat optik dan menguji efektivitasnya. Penelitian dan pengembangan (Reseach and Development) ini mengacu pada model Borg and Gall (1983) yang dimodifikasi. Teknik pengumpulan data yang digunakan adalah observasi, angket, tes dan dokumentasi. Hasil uji kelayakan menunjukkan bahwa modul pembelajaran fisika berbasis guided inquiry pada materi alat-alat optik layak digunakan dengan persentase skor kelayakan dari ahli materi sebesar $87,27 \%$ dan dari ahli media sebesar 91,67\%. Hasil uji efektifitas menunjukkan bahwa modul yang dihasilkan efektif digunakan. Hal ini ditunjukkan dengan hasil perhitungan uji $\mathrm{t}$ terhadap data tes hasil belajar peserta didik. Hasil uji $t$ diperoleh $t_{\text {tabel }}$ sebesar 2,048 dan $t_{\text {hitung }}$ sebesar 6,433 , sehingga $t_{\text {hitung }}>t_{\text {tabel }}$ yang artinya $H_{0}$ ditolak dan $H_{a}$ diterima.
\end{abstract}




\begin{abstract}
This study aims to produce guided inquiry based learning modules on optical instrument material and test their effectiveness. This research and development refers to the modified Borg and Gall (1983) model. Techniques for collecting data through observation, questionnaires, tests and documentation. The results of the feasibility test showed that the physics learning module based on guided inquiry on optical instrument material was feasible to use with the percentage of the feasibility score from the material experts amounting to $87.27 \%$ and from media experts amounting to $91.67 \%$. The effectiveness test results show that the module produced effectively. This is indicated by the results of t-test calculations on student learning outcomes test data obtained $t_{\text {table }} 2.048$ and $t_{\text {count }}$ of 6.433 , so $t_{\text {count }}>t_{\text {table }}$ which means $H_{0}$ is rejected, $H_{a}$ is accepted. C2019PERJ
\end{abstract}

Keywords: modules, physics, guided inquiry, optical instrument. 


\section{PENDAHULUAN}

Proses pembelajaran merupakan interaksi antara guru dan peserta didik, baik interaksi langsung maupun tidak langsung. Kunci utama keberhasilan pendidikan nasional ada pada pendidik. Pendidik hendaknya menciptakan kegiatan belajar mengajar yang inovatif, kreatif, dan aktif (Widodo, Sukiswo, \& Putra, 2011).

Tujuan pembelajaran adalah untuk meningkatkan penguasaan terhadap pengetahuan, konsep, dan prinsip ilmu pengetahuan, serta memiliki pengetahuan, keterampilan dan sikap ilmiah (Depdiknas, 2006). Sains atau ilmu pengetahuan alam adalah ilmu pokok yang konsepnya meliputi alam dan segala isinya (Jumadi, 2015). Salah satu ilmu sains yang menarik untuk dipelajari adalah ilmu fisika. Fisika adalah salah satu cabang ilmu sains yang berkaitan dengan cara mengetahui tentang alam secara sistematis dan suatu proses penemuan (Haloho \& Wiyono, 2016). Tujuan dari pembelajaran fisika adalah peserta didik mampu secara aktif mencari, mengolah, mengkostrusi, dan menggunakan pengetahuan. Hal ini sangat sesuai dengan kemampuan yang dibutuhkan dalam keterampilan proses sains.

Berdasarkan observasi yang dilakukan peneliti pada 4 januari 2018 di Madrasah Aliyah Nahdlatul Ulama Donorojo Jepara didapatkan informasi bahwa dalam pembelajaran fisika guru masih menggunakan metode ceramah untuk menyampaikan informasi pada peserta didik. Hal ini membuat peserta didik tidak memiliki kesempatan untuk melakukan pengamatan atau bereksperimen.

Kurangnya kemampuan di bidang sains ini dikarenakan kurangnya keterlibatan peserta didik dalam pembelajaran sains. Pembelajaran sains tidak dapat dipisahkan dari keterampilan proses sains. Oleh karena itu, untuk meningkatkan prestasi peserta didik di bidang sains maka diperlukan penerapan keterampilan proses sains dalam setiap pembelajaran sains. Keterampilan proses sains sangat membantu peserta didik agar dapat bersikap saintis dalam menyelesaikan masalah dan merencanakan percobaan. Keterlibatan peserta didik dalam pembelajaran sains dapat meningkatkan pemahaman peserta didik terhadap keterampilan proses sains dan konsep sains (Abungu, Okere, \& Wachanga, 2014).

Guided inquiry merupakan salah satu model pembelajaran yang dapat meningkatkan keterampilan proses sains peserta didik. Berdasarkan penelitian yang telah dilakukan oleh Rachmadhani (2014) dan Winarni (2012) penerapan model pembelajaran 
guided inquiry dapat meningkatkan keterampilan proses sains peserta didik (Rachmadhani, 2014; Winarni, Suparmi, \& Sarwanto, 2014). Guided Inquiry memberikan kesempatan kepada peserta didik untuk bekerja merumuskan prosedur, menganalisis hasil dan mengambil kesimpulan secara mandiri, sedangkan dalam hal menentukan topik pertanyaan dan bahan penunjang, guru hanya berperan sebagai fasilitator (Suhana, 2014).

Bahan ajar yang dirasa sesuai untuk meningkatkan keterampilan proses sains adalah bahan ajar berupa modul. Modul merupakan salah satu bentuk bahan ajar yang dikemas secara utuh dan sistematis, didalamnya memuat seperangkat pengalaman belajar yang terencana dan didesain untuk membantu peserta didik menguasai materi pembelajaran, serta evaluasi (Daryanto, 2013). Modul memiliki kelebihan sebagai desain untuk belajar mandiri karena setiap peserta didik memiliki daya tangkap belajar yang berbeda-beda (Nurjanah, Sajidan, \& Karyanto, 2016). Modul tidak hanya berfungsi untuk membangun pemahaman peserta didik namun juga dapat membantu peserta didik belajar mandiri.

Materi fisika alat-alat optik sering dijumpai peserta didik dalam kehidupan sehari-hari sehingga hal tersebut dapat memotivasi peserta didik untuk menemukan secara mandiri suatu konsep, prinsip, dan teori atau hukum. Penelitian ini bertujuan untuk menghasilkan produk berupa modul pembelajaran berbasis guided inquiry pada materi alat-alat optik dan untuk menguji efektivitas penggunaan modul pembelajaran fisika berbasis guided inquiry terhadap hasil belajar peserta didik.

\section{METODE}

Jenis penelitian ini adalah penelitian dan Pengembangan (Research and Development). Sampel yang digunakan adalah 20 peserta didik kelas XI B sebagai kelas kontrol dan 20 peserta didik kelas XI A eksperimen. Prosedur pengembangan pada penelitian ini menggunakan versi Brog and Gall, yang dibatasi sampai 7 tahap yaitu: (1) penelitian dan pengumpulan informasi (research and information collecting); (2) perencanaan (planning); (3) pengembangan format produk awal (develop preliminary field testing); (4) uji coba awal (preliminary field testing); (5) revisi hasil uji coba awal (main product revision); (6) uji coba lapangan (main field testing); (7) revisi hasil uji coba lapangan (operational product revision) (Borg, W.R. \& Gall, 1983).

Berdasarkan tahapan pengembangan versi Brog and Gall, tahap pertama yang 
dilakukan ialah research and information collection (studi pendahuluan). Tahap studi pendahuluan dibagi menjadi dua tahap, yaitu studi literatur dan studi lapangan. Tahap studi literatur dilakukan dengan mencari referensi dari jurnal-jurnal maupun buku yang relevan dengan modul yang akan dikembangankan. Tahap studi lapangan dilakukan melalui observasi secara langsung di sekolah, yaitu dengan melakukan pengamatan di kelas ketika proses pembelajaran. Pada tahap ini, modul didesain sesuai dengan rancangan. Tahapan yang ke empat yaitu uji coba awal (preliminary field testing). Uji coba awal ini dilakukan untuk mengetahui validitas modul yang dikembangkan. Validasi dilakukan dengan melibatkan masing-masing dua ahli desain dan ahli materi yang dilakukan oleh dua orang dosen pendidikan fisika Universitas Islam Negeri Walisongo Semarang dan dua orang guru fisika Madrasah Aliyah Nahdlatul Ulama Donorojo.
Presentase kelayakan dihitung dengan Persamaan (1).

$$
K=\frac{m}{e} \times 100 \%
$$

Keterangan:

$$
\begin{aligned}
K & =\text { Kelayakan } \\
m & =\text { Skor Maksimal } \\
e & =\text { Skor Empiris }
\end{aligned}
$$

Skor (\%) presentase yang sudah dihasilkan dikonversikan dalam bentuk tabel kriteria yang disajikan pada Tabel 1(Akbar, 2013).

Modul kemudian direvisi sesuai dengan saran dan kritik yang diberikan oleh validator. Hal ini merupakan tahapan yang ke lima (main product revison). Setelah data dianalisis dan dinyatakan valid oleh validator, selanjutnya dilakukan tahap uji coba lapangan (operational field testing) untuk mengukur efektifitas modul yang telah dikembangankan. Uji coba lapangan melibatkan 20 peserta didik kelas XI di Madrasah Aliyah Nahdlatul Ulama' Donorojo. Indikator yang diukur pada tahap penelitian ini adalah nilai hasil belajar peserta didik setelah menggunakan modul yang telah dikembangkan.

Tabel 1. Kriteria Kevalidan Modul

\begin{tabular}{ll}
\hline Kriteria Validasi & \multicolumn{1}{c}{ Tingkat Validasi } \\
\hline $85,01 \%-100 \%$ & Sangat valid, atau dapat digunakan tanpa revisi \\
$70,01 \%-85 \%$ & $\begin{array}{l}\text { Cukup valid, atau dapat digunakan namun perlu direvisi } \\
\text { kecil }\end{array}$ \\
$50,01 \%-70 \%$ & $\begin{array}{l}\text { Kurang valid, disarankan tidak dipergunakan karena } \\
\text { perlu revisi besar }\end{array}$ \\
& Tidak valid atau tidak boleh dipergunakan \\
\hline
\end{tabular}


Tahap terakhir dalam penelitian ini adalah revisi hasil uji coba lapangan. Modul berbasis guided inquiry yang telah dinyatakan valid dan efektif kemudian direvisi kembali untuk kesempurnaan modul.

\section{HASIL DAN PEMBAHASAN}

Produk hasil pengembangan berupa modul pembelajaran fisika berbasis guided inquiry pada materi Alat-alat Optik yang digunakan pada pembelajaran kelas XI SMA/MA. Modul didesain dengan ukuran B5 (145 mm x $250 \mathrm{~mm}$ ).

Modul yang dikembangkan berada pada kategori cukup valid sedangkan validitas desain modul termasuk dalam kategori sangat valid. Hasil analisis validitas oleh ahli materi dan ahli desain selengkapnya dapat dilihat pada Tabel 2 dan Tabel 3.

Penilaian modul berdasarkan aspek keakuratan materi termasuk pada kategori sangat baik (SB) dan sangat valid, atau dapat digunakan tanpa revisi. Aspek kebahasaan termasuk pada kategori sangat baik (SB) dan sangat valid, atau dapat digunakan tanpa revisi. Aspek penyajian termasuk pada kategori sangat baik (SB) dan sangat valid, atau dapat digunakan tanpa revisi. Aspek guided inquiry termasuk pada kategori baik (B) dan cukup valid atau dapat digunakan namun perlu direvisi kecil.
Berdasarkan hasil perhitungan, modul yang telah dikembangkan menurut para ahli materi dan guru fisika dikategorikan sangat baik (SB), dengan kriteria kelayakan cukup valid, atau dapat digunakan namun perlu direvisi kecil. Penilaian pada aspek desain menunjukkan modul berada pada kategori sangat baik (SB) dengan kriteria sangat valid, atau dapat digunakan tanpa revisi.

Hasil observasi menunjukkan bahwa pembelajaran di Madrasah Aliyah Nahdlatul Ulama Donorojo masih menggunakan metode ceramah. Penerapan model pembelajaran guided inquiry yang dikembangkan dapat memfasilitasi peserta didik untuk mengembangkan sikap ilmiahnya, yaitu sikap penemuan dan kreativitas, sikap berpikir terbuka, bekerjasama, dan sikap peka terhadap lingkungan sekitar.

Pelaksanaan pembelajaran pada kelas kontrol menggunakan metode ceramah berbantuan LKS, sedangkan pada kelas eksperimen menggunakan metode guided inquiry dengan modul pembelajaran Fisika materi Alatalat Optik berbasis guided inquiry. Setelah kelas eksperimen dan kelas kontrol diberi perlakuan kemudian dilakukan posttest yang bertujuan untuk mengetahui kemampuan yang dicapai peserta didik setelah mendapatkan pembelajaran. 
Berdasarkan hasil perhitungan uji t terhadap data tes hasil belajar peserta didik diperoleh $\mathrm{t}_{\text {hitung }}>\mathrm{t}_{\text {tabel }}$ yaitu pada $a=5 \%$ dengan $\mathrm{dk}=20+20-2=28$ diperoleh $t_{\text {tabel }} 2,048$. $t_{\text {hitung }}$ yang dihasilkan dalam penelitian sebesar 6,433 sehingga $t_{\text {hitung }}>t_{\text {tabel }}$ yang artinya $H_{0}$ ditolak, $H_{a}$ diterima. Hal ini menunjukkan bahwa hasil belajar peserta didik pada materi Alat-alat Optik berbasis guided inquiry lebih baik dibanding hasil belajar peserta didik dengan LKS sekolah Madrasah Aliyah Nahdlatul Ulama' Donorojo.
Keberhasilan peserta didik dalam belajar dipengaruhi oleh kondisi internal maupun eksternal. Salah satu faktor eksternal adalah kemampuan guru dalam memilih metode dan pendekatan pembelajaran yang tepat (Muspiroh, 2013). Penggunaan metode guided inquiry dan pendekatan scientifik yang digunakan dalam pembelajaran meliputi kegiatan mengamati, menanya, menalar, dan mencoba sangat berpengaruh terhadap hasil belajar peserta didik.

Tabel 2. Data Hasil Penilaian Modul Fisika Oleh Ahli Materi

\begin{tabular}{cccc}
\hline Aspek Penilaian & Skor total & Rata-rata & $\begin{array}{c}\text { Presentase } \\
\text { Kelayakan }\end{array}$ \\
\hline Keakuratan Materi & 38 & 4,75 & $95 \%$ \\
Kebahasaan & 26 & 4,33 & $86,67 \%$ \\
Penyajian & 18 & 4,53 & $90 \%$ \\
Guided inquiry & 14 & 3,50 & $70 \%$ \\
\hline Jumlah rata-rata skor & 96 & 4,36 & $87,27 \%$ \\
\hline
\end{tabular}

Tabel 3. Data Hasil Penilaian Modul Fisika Oleh Ahli Desain.

\begin{tabular}{llll}
\hline \multicolumn{1}{c}{ Aspek Penilaian } & Skor Total & Rata-rata & Presentase Kelayakan \\
\hline Desain Modul & 55 & 6,875 & $91,67 \%$ \\
Jumlah Skor Rata-rata & 55 & 6,875 & $91,67 \%$ \\
\hline
\end{tabular}

Menurut permendikbud No. 65 Tahun 2013, untuk memperkuat pendekatan ilmiah (scientific), tematik terpadu (tematik antar mata pelajaran), dan tematik (dalam suatu mata pelajaran) perlu diterapkan pembelajaran berbasis penyingkap/peneliti (discovery) inquiry learning). Oleh karena itu, digunakan metode guided inquiry dalam upaya meningkatkan kecakapan akademik serta prestasi belajar peserta didik. Kelebihan metode guided inquiry adalah membantu peserta didik untuk menggunakan ingatannya dan mentrasfer ke dalam situasi-situasi baru. Pembelajaran dengan 
menggunakan metode guided inquiry memiliki nilai kognitif yang tinggi dibandingkan dengan pembelajaran konvesional (Tamara \& Sunarti, 2017). Melalui guided inquiry, peserta didik diberikan kesempatan untuk merumuskan prosedur, menganalisis hasil, dan mengambil kesimpulan secara mandiri, sedangkan dalam hal menentukan topik, pertanyaan dan bahan penunjang, guru hanya berperan sebagai fasilitator (Suhana, 2014). Penelitian yang dilakukan oleh Ikhsan, Sutarno, \& Prayitno (2016) juga menyebutkan bahwa pengembangan modul berbasis inkuiri terbimbing efektif meningkatkan hasil belajar peserta didik.

Proses belajar peserta didik memiliki gaya berbeda-beda seperti visual (belajar dengan cara melihat), auditorial (belajar dengan cara mendengar), dan kinestetik (belajar dengan cara bergerak, bekerja dan menyentuh). Gaya belajar merupakan bakat yang secara potensial dimiliki oleh setiap orang untuk dapat diidentifikasi dan dipupuk melalui pendidikan yang tepat. Oleh karena itu, guided inquiry dapat dijadikan sebagai solusi karena dalam pembelajaran guided inquiry peserta didik dapat mengembangkan karakternya dan melibatkan proses-proses kognitif yang potensial dalam merangsang perkembangan intelek sehingga menyebabkan perubahan hasil belajar.

Hasil belajar dipengaruhi beberapa faktor, salah satunya yaitu keterlibatan peserta didik selama proses pembelajaran. Peserta didik pada kelas eksperimen lebih aktif untuk menemukan konsep melalui percobaan dan tanggap dengan penjelasan guru mengenai Alatalat Optik, misalnya pada sifatsifat bayangan dan peristiwa pembiasan yang terjadi pada mata dan kamera. Hal ini ditandai dengan banyaknya pertanyaan yang diberikan oleh peserta didik kelas eksperimen kepada guru, sehingga peserta didik lebih mampu dan paham dalam mengerjakan soal posttest.

Lain halnya dengan kelas eksperimen yang menggunakan modul Alat-alat Optik berbasis guided inquiry, pembelajaran pada kelas kontrol hanya menggunakan LKS sekolah Madrasah Aliyah Nahdlatul Ulama' Donorojo. Peserta didik kelas kontrol terlihat lebih pasif dibanding peserta didik pada kelas eksperimen.

Perbedaan hasil belajar antara kelas kontrol dan kelas eksperimen juga dipengaruhi oleh sumber belajar yaitu penggunaan modul. Modul merupakan salah satu bentuk bahan ajar yang dikemas secara utuh dan sistematis. Modul memuat seperangkat pengalaman belajar yang terencana dan didesain untuk membantu peserta 
didik menguasai materi belajar, serta evaluasi (Daryanto, 2013). Modul memiliki kelebihan sebagai desain untuk belajar mandiri karena setiap peserta didik memiliki daya tangkap belajar yang berbeda-beda sehingga modul dapat meningkatkan pemahaman peserta didik (Nurjanah et al., 2016). Modul tidak hanya berfungsi untuk membangun pemahaman peserta didik namun juga dapat membantu peserta didik belajar mandiri.

\section{KESIMPULAN}

Pengembangan modul fisika berbasis guided inquiry pada materi Alat-Alat Optik termasuk dalam kategori sangat valid dengan nilai validitas sebesar $87.27 \%$ untuk kategori materi dan untuk kategori desain sebesar 91.67\%. Modul fisika berbasis guided inquiry pada materi Alat-Alat Optik yang telah dikembangkan dinyatakan efektif, dibuktikan dari hasil perhitungan uji t terhadap data tes hasil belajar peserta didik diperoleh $t_{\text {hitung }}>t_{\text {tabel }}$ yang artinya $H_{0}$ ditolak, $H_{a}$ diterima.

\section{DAFTAR PUSTAKA}

Abungu, H. E., Okere, M. I. O., \& Wachanga, S. W. 2014. The Effect of Science Process Skills Teaching Approach on Secondary School Students' Achievement in Chemistry in
Nyando District, Kenya. Journal of Educational and Social Research, 3(6).

Akbar, S. 2013. Instrumen Perangkat

Pembelajaran. Bandung:

Rosdakarya.

Borg, W.R. \& Gall, M. 1983. Educational Research: An Introduction. New York: Longman.

Daryanto. 2013. Menyusun Modul (Bahan Ajar untuk Persiapan Guru dalam Mengajar). Yogyakarta: Gava Media.

Depdiknas. 2006. Pedoman Khusus Pengembangan Silabus dan Penilaian Mata Pelajaran Fisika. Jakarta: Depdiknas.

Haloho, F., \& Wiyono, K. 2016. Pengembangan Buku Kerja Peserta Didik Berbasis Inkuiri Materi Optika Geometri Kelas X Sekolah Menengah Atas. Jurnal Inovasi dan Pembelajaran Fisika, 3(1): 30-36.

Ikhsan, M., Sutarno, \& Prayitno, B. A. 2016. Materi Sistem Gerak Manusia untuk Meningkatkan Hasil Belajar Peserta didik Kelas XI MIA SMA Negeri 1 Wera. Jurnal Inkuiri, 5(1): 133142.

Jumadi, S. P. 2015. Developing A Guided Inquiry-Based Science Teaching And Learning Module To Improve Junior High School Students Processing Skill And Scientific Attitude. Universitas Negeri Yogyakarta.

Muspiroh, N. 2013. Integrasi Nilainilai Islam dalam 
Pembelajaran IPA di Sekolah. Jurnal Pendidikan Islam, 28(3): 168-188.

Nurjanah, A. K., Sajidan, \& Karyanto, $\quad$ P. 2016. Pengembangan Modul Biologi Berbasis Inquiry Real World Application Pada Materi Bioteknologi. Jurnal Inkuiri, 5(3): 66-76.

Rachmadhani, P. H. 2014. Penerapan Model Pembelajaran Inkuiri Terbimbing untuk Meningkatkan Kemampuan Berpikir Kreatif dan Keterampilan Proses Sains Peserta didik Kelas X-MIA 1 SMA Negeri 1 Gondang Tulungagung. Universitas Negeri Malang.

Suhana, C. 2014. Konsep Strategi Pembelajaran (Edisi Revisi). Bandung: PT. Refika Aditama. Tamara, A. F., \& Sunarti, T. 2017. Penerapan Model Pembelajaran Guided Inquiry untuk Meningkatkan

Kemampuan Literasi Sains Peserta Didik pada Materi Elastisitas di SMAN 1 Plemahan Kediri. Jurnal Inovasi Pendidikan Fisika, 6(3): 1-5.

Widodo, S., Sukiswo, S. E., \& Putra, N. M. D. 2011. Penerapan Pembelajaran Kooperatif Model Numbered Head Together untuk Meningkatkan Hasil Belajar Peserta didik Kelas VII SMP pada Pokok Bahasan Besaran dan Pengukuran. Jurnal Pendidikan Fisika Indonesia, 7(1): 42-46.

Winarni, Suparmi, \& Sarwanto. 2014. Pengembangan Modul Berbasis Inkuiri Terbimbing pada Pokok Bahasan Kalor untuk SMA/MA Kelas X. Inkuiri, 3(01): 1-10. 